medRxiv preprint doi: https://doi.org/10.1101/2020.05.19.20106906; this version posted May 26, 2020. The copyright holder for this preprint (which was not certified by peer review) is the author/funder, who has granted medRxiv a license to display the preprint in perpetuity.

All rights reserved. No reuse allowed without permission.

\title{
Efficacy and Safety of Hydroxychloroquine and Chloroquine for COVID-19: A
}

\section{Systematic Review}

Sonal Singh, MD, MPH ${ }^{1}$, Thomas J. Moore, $\mathrm{AB}^{2,3}$

1 Department of Family Medicine and Community Health, Meyers Primary Care Institute and

Quantitative Health Sciences, University of Massachusetts Medical School, Worcester, Massachusetts, USA

2. Center for Drug Safety and Effectiveness, Johns Hopkins Bloomberg School of Public Health, Baltimore, MD, USA

3. Department of Epidemiology, The George Washington University Milken Institute School of Public Health, Washington, DC, USA

Address for correspondence:

Sonal Singh, MD, MPH

Department of Family Medicine and Community Health \& Meyers Primary Care Institute and Quantitative Health Sciences

University of Massachusetts Medical School

55 Lake Ave North

Worcester, MA 01655-0002 USA

Tel: 7744426611

Sonal.Singh@umassmemorial.org

Word Count (including Abstract): 3068

Abstract: 270

Key Words: Hydroxychloroquine, chloroquine, SARS-CoV-2, COVID-19, systematic review

Conflicts of Interest: SS does not report any conflicts of interest related to the contents of this manuscript. TJM does not report any conflicts of interested related to the contents of this manuscript. 
medRxiv preprint doi: https://doi.org/10.1101/2020.05.19.20106906; this version posted May 26, 2020. The copyright holder for this preprint (which was not certified by peer review) is the author/funder, who has granted medRxiv a license to display the preprint in perpetuity.

All rights reserved. No reuse allowed without permission.

Contribution: SS drafted the study protocol. Both the authors (SS and TJM) contributed to the search, data extraction, review and interpretation and preparation of the manuscript. SS will act as guarantor of the manuscript.

\section{Key Points}

- We conducted a systematic review of the efficacy and safety of hydroxychloroquine and chloroquine among patients hospitalized with COVID19 and identified 14 studies reporting on clinical or virologic outcomes and 6 additional studies reporting on the QT interval.

- Hydroxychloroquine or chloroquine improved virologic outcomes in 2 clinical studies and cough in another study.

- Most studies either reported an increased risk of mortality ( $\mathrm{n}=2$ studies) or need for respiratory support ( $\mathrm{n}=1$ study) or no beneficial effects on pneumonia/intubation or death ( $\mathrm{n}=8$ studies).

- The proportion of participants with critical QTc $\geq 500 \mathrm{~ms}$ or an increase $\geq 60$ ms ranged from $8.3 \%$ to $36 \%$ ( $n=8$ studies). 
medRxiv preprint doi: https://doi.org/10.1101/2020.05.19.20106906; this version posted May 26, 2020. The copyright holder for this preprint (which was not certified by peer review) is the author/funder, who has granted medRxiv a license to display the preprint in perpetuity.

All rights reserved. No reuse allowed without permission.

\section{BACKGROUND}

Hydroxychloroquine and chloroquine are widely used to treat hospitalized COVID-19 patients primarily based on antiviral activity in in vitro studies. Our objective was to systematically evaluate their efficacy and safety in hospitalized patients with COVID-19.

\section{METHODS}

We systematically reviewed PubMed, ClinicalTrials.gov, and Medrxviv for studies of hydroxychloroquine and chloroquine in COVID-19 hospitalized patients on April 26, 2020. We evaluated the quality of trials and observational studies using the Jadad criteria and Newcastle Ottawa Scale, respectively.

\section{RESULTS}

After a review of 175 citations, we included 5 clinical trials (total of 345 patients), 9 observational studies $(n=2529)$, and 6 additional studies $(n=775)$ reporting on the QT interval. Three studies reported treatment benefits including two studies reporting benefit on virologic outcomes, which was statistically significant in one study, and another reported significant improvement on cough symptoms. Three studies reported that treatment was potentially harmful, including an significantly increased risk of mortality in two studies and increased need for respiratory support in another. Eight studies were unable to detect improvements on virologic outcomes $(n=3)$ or pneumonia or transfer to ICU/death $(n=5)$. The proportion of participants with critical QTc intervals of $\geq 500 \mathrm{~ms}$ or an increase of $\geq 60 \mathrm{~ms}$ from baseline ranged from $8.3 \%$ to $36 \%(n=8)$. One clinical trial and six observational studies were of good quality. The remaining studies were of poor quality. 
medRxiv preprint doi: https://doi.org/10.1101/2020.05.19.20106906; this version posted May 26, 2020. The copyright holder for this preprint (which was not certified by peer review) is the author/funder, who has granted medRxiv a license to display the preprint in perpetuity.

All rights reserved. No reuse allowed without permission.

\section{CONCLUSIONS}

Our systematic review of reported clinical studies did not identify substantial evidence to support the efficacy of hydroxychloroquine or chloroquine in hospitalized COVID-19 patients and raises questions about potential harm from QT prolongation and increased mortality. 
medRxiv preprint doi: https://doi.org/10.1101/2020.05.19.20106906; this version posted May 26, 2020. The copyright holder for this preprint (which was not certified by peer review) is the author/funder, who has granted medRxiv a license to display the preprint in perpetuity.

All rights reserved. No reuse allowed without permission.

\section{INTRODUCTION}

There are no known effective drugs for acute respiratory syndrome coronavirus-2 (SARS-CoV2). Hydroxychloroquine and chloroquine raise the endosomal $\mathrm{pH}$ required for virus/cell fusion and interfere with the glycosylation of SARS-corona virus to the cell-surface receptor. ${ }^{1}$

Chloroquine is a potent inhibitor of SARS-CoV-1 coronavirus infection in primate cell cultures, ${ }^{2}$ and both have antiviral activity in vitro against SARS-CoV-2. ${ }^{34}$ They also have adverse effects, including prolongation of the QT interval, ${ }^{5}$ retinal damage, psoriasis outbreaks, myopathy, and suicidal behaviors. ${ }^{6}$ The two drugs are inexpensive and approved for prevention of malaria and treatment of lupus and rheumatoid arthritis.

The two drugs were heralded as a "breakthrough" treatment based on preliminary data, ${ }^{7}$ and their use grew exponentially in patients with COVID-19. A global survey of 6150 physicians reported that $55 \%$ had used hydroxychloroquine. ${ }^{8}$ Monthly average outpatient hydroxychloroquine prescriptions in the United States increased from 15,000 to 139,000 in March 2020 compared to prior years. ${ }^{9}$ The U.S. Food and Drug Administration (FDA) granted an emergency use authorization for treatment of the virus in hospitalized patients, ${ }^{10}$ and made supplies from the national emergency stockpile available to hospitals despite noting that dose and duration were unknown. Although several international agencies recommended use, ${ }^{7}$ an National Institutes of Health panel did not find sufficient evidence to recommend for or against use. ${ }^{11}$ In April 2020, the FDA issued a Drug Safety Communication warning of the cardiovascular risks of the two drugs. ${ }^{12}$ Our objective was to systematically evaluate the efficacy of hydroxychloroquine and chloroquine in hospitalized patients with COVID-19. 
medRxiv preprint doi: https://doi.org/10.1101/2020.05.19.20106906; this version posted May 26, 2020. The copyright holder for this preprint (which was not certified by peer review) is the author/funder, who has granted medRxiv a license to display the preprint in perpetuity.

\section{METHODS}

\section{Data Sources and Systematic Search Strategy}

We searched PubMed, ClinicalTrials.gov, and Medrxviv for studies of patients hospitalized with COVID-19 and treated with hydroxychloroquine, chloroquine, and/or combinations with antibiotics. We initially searched PubMed for studies published from November 1, 2019, to April 26, 2020. From Clinicaltrials.gov, we extracted studies with results reported as of April 26, 2020. We also searched for preprints at medrxviv.com with similar terms and signed up to receive electronic notification of new articles through May 10, 2020. We reviewed the references of included studies for additional studies. Our search strategy is shown in the

\section{Supplementary Table S1.}

\section{Eligibility Criteria}

We included both published and unpublished clinical trials and observational studies that reported on chloroquine and hydroxychloroquine use either as a single drug or in combination with azithromycin to treat patients hospitalized patients with COVID-19. We excluded case reports and in vitro studies.

\section{Outcomes}

The included clinical studies reported on any of the following outcomes: virologic clearance as measured by polymerase chain reaction (PCR) or culture, symptom improvement (e.g., cough), improvement in radiological assessment of pneumonia, hospital discharge and need for intubation or respiratory support or death. Additionally, we analyzed separately studies 
medRxiv preprint doi: https://doi.org/10.1101/2020.05.19.20106906; this version posted May 26, 2020. The copyright holder for this preprint (which was not certified by peer review) is the author/funder, who has granted medRxiv a license to display the preprint in perpetuity.

All rights reserved. No reuse allowed without permission.

reporting on QT prolongation.

\section{Study Selection}

Two reviewers evaluated the citations to identify relevant studies. We resolved discrepancies through discussion after review of full texts and achieved full agreement prior to inclusion.

\section{Data Extraction}

We extracted data on study design, location, number of hospitals, outcomes, interventions, and control including dose and duration of the study drug and measures of statistical significance.

\section{Quality Assessment}

We evaluated the quality of clinical trials using the Jadad criteria ${ }^{13}$ and the quality of observational studies using the Newcastle Ottawa Scale. ${ }^{14}$ Controlled observational studies were classified as being good, fair, or poor based on their performance on measures of selection, comparability, and outcomes. We rated all uncontrolled studies as being of poor quality.

\section{Data Synthesis}

We conducted a qualitative synthesis of the evidence since the data were too heterogeneous to be pooled in a meta-analysis. 
medRxiv preprint doi: https://doi.org/10.1101/2020.05.19.20106906; this version posted May 26, 2020. The copyright holder for this preprint (which was not certified by peer review) is the author/funder, who has granted medRxiv a license to display the preprint in perpetuity.

\section{RESULTS}

\section{Search Results}

The results of our search are shown in the flow sheet in Figure 1.

Our search identified 175 citations. After a review of citations, we included 5 clinical trials ${ }^{15-19} 7$ controlled observational studies, ${ }^{20-26}$ and 2 uncontrolled observational studies on clinical outcomes. ${ }^{27} 28$ Six uncontrolled studies reporting on changes in the QT interval were also evaluated separately. ${ }^{29-34}$ In case of duplicate publication, we extracted data from the most recent study. ${ }^{29} 35$

\section{Study Characteristics}

The characteristics of clinical trials and observational studies are shown in Table 1. Four clinical trials were conducted in China ${ }^{15-1719}$ and one in Brazil. ${ }^{18}$ The total number of participants enrolled in the trials was 345 and the sample size of clinical trials ranged from $22^{19}$ to $150 .{ }^{15}$ Three clinical trials evaluated hydroxychloroquine vs usual care, ${ }^{15-17}$ one evaluated chloroquine vs lopinavir/ritonavir, and another evaluated high-dose chloroquine (600 mg twice daily for 10 days) vs low-dose chloroquine (450 mg twice daily for 5 days). ${ }^{18}$

Among the nine observational studies reporting on clinical outcomes, four were conducted in France, ${ }^{20} 222728$ three in the United States, ${ }^{25} 2126$ and two in China. ${ }^{2324}$ The sample size of observational studies ranged from $11^{27}$ to $1446 .{ }^{26}$ Two studies reported on the use of chloroquine,$^{23}{ }^{24}$ while the remaining studies evaluated either hydroxychloroquine alone 212225 or in combination with azithromycin. 
medRxiv preprint doi: https://doi.org/10.1101/2020.05.19.20106906; this version posted May 26, 2020. The copyright holder for this preprint (which was not certified by peer review) is the author/funder, who has granted medRxiv a license to display the preprint in perpetuity.

All rights reserved. No reuse allowed without permission.

Among the six studies exclusively reporting on the QT interval as an outcome, three were conducted in the United States, ${ }^{30} 3334$ one in France, ${ }^{32}$ and another in the Netherlands. ${ }^{31}$ In addition, one multicenter study was conducted in the United States and Italy. ${ }^{29}$ Five studies evaluated hydroxychloroquine + azithromycin, ${ }^{29} 30$ 32-34 and one evaluated chloroquine alone. ${ }^{31}$ One study evaluated all three drugs. ${ }^{34}$

\section{Study Quality}

The quality assessments of clinical trials and observational studies is shown in

Supplementary Figures S1 and S2, respectively. Randomization was adequately reported in only two clinical trials, ${ }^{15} 18$ whereas the remaining trials did not provide adequate details of randomization. ${ }^{16} 1719$ One trial was appropriately double masked, ${ }^{18}$ and another reported that neither the investigators or participants were aware of treatment assignment, but did not describe details of blinding. ${ }^{16}$ One trial was open label in which neither the participants, investigator or outcome assessors were blinded, ${ }^{15}$ and the remaining three trials did not report on blinding., 1719 Two trials reported on dropouts. ${ }^{1718}$ Only three clinical trials were peer reviewed. ${ }^{17-19}$ Two trials reported an intention to treat analysis. ${ }^{17} 18$

Among nine observational studies reporting on clinical outcomes, six controlled observational studies were rated as being of good quality, ${ }^{202123-26}$ whereas one controlled observational study, ${ }^{22}$ and the two uncontrolled studies, ${ }^{27} 28$ were of poor quality. Four studies were peer reviewed, ${ }^{22} 26-28$ five were not. ${ }^{20} 21$ 23-25 
medRxiv preprint doi: https://doi.org/10.1101/2020.05.19.20106906; this version posted May 26, 2020. The copyright holder for this preprint (which was not certified by peer review) is the author/funder, who has granted medRxiv a license to display the preprint in perpetuity.

All rights reserved. No reuse allowed without permission.

All six uncontrolled studies reporting on QT interval alone were rated as being of poor quality, ${ }^{29-34}$ and four were peer reviewed. ${ }^{31-34}$

\section{Results on Benefits and Harms}

The results on potential benefits and harms is shown in Table 2. Among those reporting potential benefits, two observational studies reported beneficial effects on virologic clearance with the combination of azithromycin and hydroxychloroquine, ${ }^{22} 28$ and one clinical trial reported a statistically significant benefit in a reduction in cough remission time. ${ }^{17}$ Three studies reported an increase in potential harms including increasing need for respiratory support ${ }^{25}$ and increasing mortality with high-dose chloroquine ${ }^{18}$ and hydroxychloroquine. ${ }^{21}$ The remaining studies did not detect any statistically significant difference in either virologic clearance, ${ }^{16} 192427$, pneumonia, ${ }^{17} 1923$ transfer to ICU or death, ${ }^{20} 26$ or intubation or death. ${ }^{26}$

\section{Virologic Clearance}

One controlled observational study reported statistically significantly increased virologic clearance with hydroxychloroquine compared to controls ( $n=26,70 \%$ vs $12 \%$; $p<0.001$ ); and with hydroxychloroquine + azithromycin vs controls $(n=6,100 \%$ vs $12 \% ; p<0.001) .{ }^{22}$ An uncontrolled observational study from the same hospital which included a few participants from the earlier study reported that $93 \%$ of 80 initial participants were PCR negative at Day $8 .^{28}$ In contrast, there was no statistically significant difference on virologic clearance in two clinical trials that evaluated hydroxychloroquine against controls, ${ }^{15} 16$ and in one clinical trial ${ }^{10}$ and another observational study ${ }^{24}$ that evaluated chloroquine and controls. ${ }^{19}{ }^{24}$ Another 
medRxiv preprint doi: https://doi.org/10.1101/2020.05.19.20106906; this version posted May 26, 2020. The copyright holder for this preprint (which was not certified by peer review) is the author/funder, who has granted medRxiv a license to display the preprint in perpetuity.

All rights reserved. No reuse allowed without permission.

uncontrolled study reported low rates of virologic clearance in 2/10 (20\%) participants on hydroxychloroquine + azithromycin.$^{27}$

\section{Clinical Outcomes}

One trial enrolling 30 patients reported statistically significant improvement in remission of symptoms of cough with hydroxychloroquine compared to controls, ${ }^{16}$ although there was no difference in symptom improvement in one trial, ${ }^{15}$ or clinical recovery in another. ${ }^{19}$ Borba et al reported no significant difference in the need for mechanical ventilation $(20 \%$ vs $10.5 \%$; $p=$ 0.41 ) at Day 6 between high-dose and low-dose chloroquine arms in a clinical trial. ${ }^{18}$ Barbosa et al reported a statistically significant increased need for respiratory support with hydroxychloroquine compared to the usual care in both the overall cohort and the matched sub-cohort, ${ }^{25}$ Mahevas et al reported no significant difference in the need for transfer to ICU or death between hydroxychloroquine and usual care (RR 0.93; 0.48-1.81) in an observational study. ${ }^{20}$ Magagnoli et al reported no significant difference in the need for ventilation when comparing vs control either hydroxychloroquine (adjusted Hazard Ratio [aHR] 1.43; 95\% Cl 0.53-3.79) hydroxychloroquine + azithromycin (aHR 0.43; 95\% $\mathrm{Cl} 0.16-1.12$ ) respectively in an observational study. ${ }^{21}$ In the largest propensity matched database study conducted in the US, ${ }^{26}$ patients on hydroxychloroquine were more likely to have the primary endpoint of intubation or death in the unadjusted analysis (HR 2.37; 95\% Cl 1.84-3.02), but there was no statistically significant difference between hydroxychloroquine and control in the main analysis using inverse probability weighting according to propensity score (aHR 1.04; 95\% Cl 0.82- 
medRxiv preprint doi: https://doi.org/10.1101/2020.05.19.20106906; this version posted May 26, 2020. The copyright holder for this preprint (which was not certified by peer review) is the author/funder, who has granted medRxiv a license to display the preprint in perpetuity.

All rights reserved. No reuse allowed without permission.

1.32). Three studies reported no significant difference in the risk of pneumonia between chloroquine and controls. ${ }^{16} 1923$ There was no statistically significant difference in either hospital stay in one observational study, ${ }^{24}$ or in hospital discharge in a clinical trial. ${ }^{19}$

\section{Mortality}

Borba et al compared high-dose chloroquine to low-dose chloroquine and the trial was prematurely halted because of statistically significantly increased mortality in the high-dose chloroquine arm (39\% vs $15 \%$; Odds Ratio $3.6,95 \% \mathrm{Cl}, 1.2-10.6) .{ }^{18}$ Magagnoli et al also reported a statistically significantly increased risk of mortality with hydroxychloroquine compared to control (aHR 2.61; 95\% Cl 1.1-6.17), but not for hydroxychloroquine + azithromycin (aHR 1.14; 95\% Cl 0.56-2.32). ${ }^{21}$ Geleris et al reported an unadjusted excess of deaths among participants in the hydroxychloroquine arm compared to controls (157/811 vs $75 / 565 ; 19.3 \%$ vs $13.3 \%$ ) without conducting any formal tests of statistical significance, although hydroxychloroquine treated patients were more severely ill at baseline. ${ }^{26}$ One small trial reported no deaths among any participants at the end of the study, ${ }^{17}$ whereas the remaining controlled studies reported small numbers of deaths without meaningful difference between groups. ${ }^{20} 2225$

\section{QT Prolongation}

A critical QTc interval $\geq 500 \mathrm{~ms}$ or an increase $\geq 60 \mathrm{~ms}$ was noted in a clinical trial, ${ }^{18} \mathrm{a}$ controlled observational study, ${ }^{20}$ and six uncontrolled studies, ${ }^{29-34}$ with proportions of treated patients affected ranging from $8.3 \%{ }^{20}$ to $36 \%$ as shown in Figure $2 .{ }^{32}$ 
medRxiv preprint doi: https://doi.org/10.1101/2020.05.19.20106906; this version posted May 26, 2020. The copyright holder for this preprint (which was not certified by peer review) is the author/funder, who has granted medRxiv a license to display the preprint in perpetuity.

All rights reserved. No reuse allowed without permission.

Borba et al showed a statistically significant higher risk of QTc $\geq 500 \mathrm{~ms}$ in the high-dose chloroquine arm compared to low-dose chloroquine (18.9\% vs $11.1 \%),{ }^{18}$ and Mahevas et al reported that a higher number of participants on hydroxychloroquine experienced QTC prolongation $\geq 60 \mathrm{~ms}$ compared to none in controls $(8.3 \% \mathrm{vs} 0 \%){ }^{20}$

The combination of hydroxychloroquine + azithromycin caused a statistically significantly increased risk of QT prolongation compared with hydroxychloroquine alone in four studies. ${ }^{31-34}$ Bessiere et al $(n=40)$ reported $33 \%$ vs 5\% $(p=0.03)$ experienced QTc $\geq 500$ ms for the combination with azithromycin vs hydroxychloroquine alone and also reported that $93 \%$ of patients in both groups combined had QT prolongation compared to baseline. ${ }^{32}$ Mercuro et al ( $n=90)$ reported a statistically significant median (Interquartile range [IQR]) increase in QT interval in the combination of hydroxychloroquine + azithromycin compared to hydroxychloroquine alone (23 seconds; (IQR) [10 seconds - 40 seconds ] vs 5.5 seconds; IQR $\left[-15.5\right.$ seconds to 34.25 seconds]; P=.03). ${ }^{33}$ Saleh et al reported that the maximum QTC was significantly longer in the combination vs monotherapy group ( $\mathrm{n}=201 ; 470.4 \mathrm{~ms}+/-45$ ms vs 453.3ms +/-37 ms; $p=0.004),{ }^{34}$ although critical QTc > 500 ms was not different between the groups. Van den Broek et al $(n=95)$ reported that the mean QTc prolongation was $34 \mathrm{~ms}(95 \% \mathrm{Cl} 25-43 \mathrm{~ms}) \cdot{ }^{31}$

Two studies reported the occurrence of torsades de pointes on treatment, ${ }^{29}{ }^{33}$ whereas six studies specifically reported the absence of torsades. ${ }^{25}$ 30-32 3435 Borba et al reported that two of the participants in the high-dose chloroquine experienced ventricular tachycardia compared to no participants in the low-dose arm. ${ }^{18}$ 


\section{DISCUSSION}

Our systematic review shows that $11 / 14$ (78.6\%) of the clinical studies either reported evidence of increased harms $(n=3)$ or detected no beneficial effects $(n=8)$. In the studies reporting treatment benefits, efficacy was mainly limited to effects on virologic clearance $(n=2$ studies) or cough ( $\mathrm{n}=1$ study), without detecting improvements in the risk of pneumonia, need for mechanical ventilation, or mortality. In contrast, the safety data raise concerns about an increased need for respiratory support, ${ }^{25}$ mortality, ${ }^{1821}$ and critical QT prolongation. ${ }^{18} 20$ 29-34

The beneficial effects on virologic clearance reported from two studies, ${ }^{22}{ }^{28}$ need to be weighed against the lack of effect on virologic outcomes from several other studies, 1517192427 and those reporting potential harms. ${ }^{182021}$ Also, one of the studies reporting increased virologic clearance ${ }^{22}$ was later deemed not to meet the International Society of Antimicrobial Chemotherapy expected journal standards. ${ }^{36}$ An independent Bayesian re-analysis concluded that the study was unable to determine the clinical effect of hydroxychloroquine on SARS-CoV2 viral load reduction because it did not compute the effect of monotherapy against controls. ${ }^{37}$ We noted critical QTc prolongation in all eight studies reporting on this endpoint, ${ }^{18} 2029-34$ with four studies reporting that the adverse effects increased with concomitant azithromycin therapy. ${ }^{31-34}$ This new group of studies advances the strength of the evidence implicating hydroxychloroquine since the prescribing information cites only an unspecified number of postmarketing reports. ${ }^{6}$ 
medRxiv preprint doi: https://doi.org/10.1101/2020.05.19.20106906; this version posted May 26, 2020. The copyright holder for this preprint (which was not certified by peer review) is the author/funder, who has granted medRxiv a license to display the preprint in perpetuity.

All rights reserved. No reuse allowed without permission.

Our systematic review should be distinguished from the results of existing systematic reviews. ${ }^{38-43}$ One review included in vitro studies, editorials, opinion letters, expert consensus, and guidelines. ${ }^{39}$ Shah et $a^{41}$ included only one study ${ }^{22}$ and an incomplete trial without any results. Another review did not identify any human studies to support the prophylactic use of hydroxychloroquine and chloroquine in COVID-19.40 Chowdhury et a ${ }^{\beta 8}$ was limited to 6 completed studies, ${ }^{15-17} 192228$ and another study with incomplete data. ${ }^{7}$ Another review ${ }^{42}$ was also limited to 7 studies and combined heterogeneous trials with observational studies in a single meta-analysis. ${ }^{16} 222817272944$ A recent recommendation from the American College of Physicians also concluded that there was insufficient evidence to support the use of hydroxychloroquine or chloroquine for treatment of patients with COVID-19.43 Our analysis added additional studies reporting on mortality, ${ }^{182126}$ respiratory support ${ }^{25}$ and QTC prolongation. 20 29-34

During the preparation of the manuscript, we received electronic notification of the publication of two other studies. ${ }^{44} 45$ A observational study of 1438 hospitalized COVID-19 patients from 24 hospitals in New York City (59.7\% male, median age 63 years) reported no significant differences in mortality for patients receiving hydroxychloroquine + azithromycin (HR, 1.35 [95\% Cl, 0.76-2.40]), or hydroxychloroquine alone (HR, 1.08 [95\% Cl, 0.63-1.85]) compared to controls. ${ }^{45}$ The combination with azithromycin was associated with higher risk of QT prolongation and cardiac arrest. An uncontrolled observational study from the same French hospital with two prior reports, ${ }^{22} 28$ focused on outcomes for 1061 SARS-CoV-2 positive patients treated with hydroxychloroquine and azithromycin and reported that a virologic cure and good clinical outcomes were obtained in $91.7 \%$ of patients, with a case fatality rate of 
medRxiv preprint doi: https://doi.org/10.1101/2020.05.19.20106906; this version posted May 26, 2020. The copyright holder for this preprint (which was not certified by peer review) is the author/funder, who has granted medRxiv a license to display the preprint in perpetuity.

All rights reserved. No reuse allowed without permission.

$0.96 \% .{ }^{44}$ The lack of a control group and the large amounts of missing data preclude any definitive conclusions. A complete evaluation of these studies will be conducted with the next updated search. However, these findings are consistent with our review. Also, this treatment is currently under investigation in several clinical trials and observational studies, which will further clarify the nature of benefit and risk.

Our systematic review has limitations, many of which reflect the quality of underlying data. The methodologic quality of many studies was poor, as noted by others. ${ }^{46}$ Except for a few studies that reported an increased mortality, ${ }^{1821}$ or no difference in the risk of intubation/death, ${ }^{26}$ the remaining studies were underpowered to detect significant differences in mortality. Few studies reported a formal hypothesis to determine an adequate sample size sufficient to detect the treatment benefit under study and thus may have not detected smaller treatment benefits. A meta-analysis was not feasible because of heterogeneous and novel clinical scales and surrogate endpoints that were not uniform among studies. The interpretation of many of the QT studies was limited by the absence of a control group, assessment of the underlying severity of the illness, and concomitant use of QT prolonging therapies. ${ }^{18} 32$ In addition, the QT interval studies were too small or uncontrolled to establish a risk of life-threatening cardiac arrythmia.

\section{CONCLUSION}

Our systematic review of clinical studies did not provide substantial evidence to support the treatment benefits of hydroxychloroquine or chloroquine in hospitalized COVID-19 patients. Accumulating evidence now raises questions of potential harm including the risk of critical QTC prolongation and increased mortality which deserve further exploration. 
medRxiv preprint doi: https://doi.org/10.1101/2020.05.19.20106906; this version posted May 26, 2020. The copyright holder for this preprint (which was not certified by peer review) is the author/funder, who has granted medRxiv a license to display the preprint in perpetuity.

All rights reserved. No reuse allowed without permission.

\section{SOURCES OF FUNDING:}

None

CONFLICTS OF INTEREST:

None

ACKNOWLEDGMENT:

None 
medRxiv preprint doi: https://doi.org/10.1101/2020.05.19.20106906; this version posted May 26, 2020. The copyright holder for this preprint (which was not certified by peer review) is the author/funder, who has granted medRxiv a license to display the preprint in perpetuity.

All rights reserved. No reuse allowed without permission.

\section{Tables}

Table 1. Clinical studies of chloroquine and hydroxychloroquine in patients hospitalized with COVID-19

Table 2. Virologic and clinical outcomes for hydroxychloroquine and chloroquine in patients hospitalized with COVID-19

Figures

Figure 1. Flow Sheet of Included Studies

Figure 2. Critical QTc Prolongation in Studies of Chloroquine/ Hydroxychloroquine in Patients with COVID-19

\section{Supplementary File}

Table S1. Search strategy

Figure S1 Quality Assessment of Clinical Trials of Chloroquine/Hydroxychloroquine in COVID-19

Figure S2. Quality Assessment of Controlled Observational Studies of Chloroquine/Hydroxychloroquine in COVID-19 
medRxiv preprint doi: https://doi.org/10.1101/2020.05.19.20106906; this version posted May 26, 2020. The copyright holder for this preprint (which was not certified by peer review) is the author/funder, who has granted medRxiv a license to display the preprint in perpetuity.

\section{REFERENCES}

1. Savarino A, Boelaert JR, Cassone A, et al. Effects of chloroquine on viral infections: an old drug against today's diseases? The Lancet Infectious Diseases 2003;3(11):722-7. doi: 10.1016/s14733099(03)00806-5 [published Online First: 2003/11/01]

2. Vincent MJ, Bergeron $E$, Benjannet $S$, et al. Chloroquine is a potent inhibitor of SARS coronavirus infection and spread. Virology Journal 2005;2(1):69. doi: 10.1186/1743-422X-2-69

3. Wang $M$, Cao R, Zhang $L$, et al. Remdesivir and chloroquine effectively inhibit the recently emerged novel coronavirus (2019-nCoV) in vitro. Cell Research 2020;30(3):269-71. doi: 10.1038/s41422020-0282-0 [published Online First: 2020/02/06]

4. Yao X, Ye F, Zhang M, et al. In Vitro Antiviral Activity and Projection of Optimized Dosing Design of Hydroxychloroquine for the Treatment of Severe Acute Respiratory Syndrome Coronavirus 2 (SARS-CoV-2). Clinical Infectious Diseases 2020 doi: 10.1093/cid/ciaa237

5. Giudicessi JR, Noseworthy PA, Friedman PA, et al. Urgent Guidance for Navigating and Circumventing the QTc-Prolonging and Torsadogenic Potential of Possible Pharmacotherapies for Coronavirus Disease 19 (COVID-19). Mayo Clinic Proceedings 2020 doi: https://doi.org/10.1016/i.mayocp.2020.03.024

6. U.S. Food and Drug Administration. Plaquenil Hydroxychloroquine Sulfate USP: Food and Drug Administration; 2006 [cited 2020 May 3]. Available from: https://www.accessdata.fda.gov/drugsatfda docs/label/2007/009768s041lbl.pdf accessed May 152020.

7. Gao J, Tian Z, Yang X. Breakthrough: Chloroquine phosphate has shown apparent efficacy in treatment of COVID-19 associated pneumonia in clinical studies. Bioscience Trends 2020;14(1):72-73. doi: 10.5582/bst.2020.01047 [published Online First: 2020/02/20]

8. Sermo. Covid-19 Treatment Patterns Among Frontline Physicians [Press release]. New York: Sermo; 2020 [updated May 7; cited 2020 May 10]. Available from: https://publiccdn.sermo.com/covid19/2f/fd24/242d23/2d233e42dc9fb34504bbf31b2f/treatment-week6.png accessed May 102020.

9. Ellen Gabler and Michael H Keller. Prescriptions Surged as Trump Praised Drugs in Coronavirus Fight. New York Times. New York: The New York Times Company, 2020:1.

10. U.S. Food and Drug Administration. Fact Sheet for Health Care Providers. Emergency Use Authorization(EUA) of Hydroxychloroquine sulfate supplied from the Strategic National Stockpile for Treatment of Covid-19 in certain Hospitalized patients. 2020 [March 282020. Available from: https://www.fda.gov/media/136537/download.

11. U.S. National Institutes of Health. NIH- COVID 19 Treatment Guidelines [Web]. 2020 [cited 2020 April 21]. Available from: https://covid19treatmentguidelines.nih.gov/introduction/ accessed April 2120202020.

12. U.S. Food and Drug Administration. FDA cautions against use of hydroxychloroquine or chloroquine for COVID-19 outside of the hospital setting or a clinical trial due to risk of heart rhythm problems 2020 [updated April 24 2020. Available from: https://www.fda.gov/drugs/drugsafety-and-availability/fda-cautions-against-use-hydroxychloroquine-or-chloroquine-covid-19outside-hospital-setting-or. 
medRxiv preprint doi: https://doi.org/10.1101/2020.05.19.20106906; this version posted May 26, 2020. The copyright holder for this preprint (which was not certified by peer review) is the author/funder, who has granted medRxiv a license to display the preprint in perpetuity. All rights reserved. No reuse allowed without permission.

13. Jadad AR, Moore RA, Carroll D, et al. Assessing the quality of reports of randomized clinical trials: is blinding necessary? Controlled Clinical Trials 1996;17(1):1-12. doi: 10.1016/01972456(95)00134-4 [published Online First: 1996/02/01]

14. GA Wells BS, D O'Connell, J Peterson, V Welch, M Losos, P Tugwell, . NEWCASTLE - OTTAWA QUALITY ASSESSMENT SCALECOHORT STUDIES Ottawa, Ontario K1J 8M5, Canada: Ottawa Hospital; [Available from: http://www.ohri.ca/programs/clinical epidemiology/nosgen.pdf accessed April 1420202020.

15. Tang W, Cao Z, Han M, et al. Hydroxychloroquine in patients with COVID-19: an open-label, randomized, controlled trial. medRxiv 2020:2020.04.10.20060558. doi: 10.1101/2020.04.10.20060558

16. Chen Z, Hu J, Zhang Z, et al. Efficacy of hydroxychloroquine in patients with COVID-19: results of a randomized clinical trial. medRxiv 2020:2020.03.22.20040758. doi: 10.1101/2020.03.22.20040758

17. CHEN Jun LD, LIU Li,LIU Ping,XU Qingnian,XIA Lu,LING Yun,HUANG Dan,SONG Shuli,ZHANG Dandan,QIAN Zhiping,LI Tao,SHEN Yinzhong,LU Hongzhou. A pilot study of hydroxychloroquine in treatment of patients with common coronavirus disease-19 (COVID-19). J Zhejiang Univ (Med Sci) 2020;49(1):0-0. doi: 10.3785/j.issn.1008-9292.2020.03.03

18. Borba MGS, Val FFA, Sampaio VS, et al. Effect of High vs Low Doses of Chloroquine Diphosphate as Adjunctive Therapy for Patients Hospitalized With Severe Acute Respiratory Syndrome Coronavirus 2 (SARS-CoV-2) Infection: A Randomized Clinical Trial. JAMA Network Open 2020;3(4.23):e208857-e57. doi: 10.1001/jamanetworkopen.2020.8857

19. Huang M, Tang T, Pang P, et al. Treating COVID-19 with Chloroquine. Journal of Molecular Cell Biology 2020 doi: 10.1093/jmcb/mjaa014

20. Mahevas M, Tran V-T, Roumier M, et al. No evidence of clinical efficacy of hydroxychloroquine in patients hospitalized for COVID-19 infection with oxygen requirement: results of a study using routinely collected data to emulate a target trial. medRxiv 2020:2020.04.10.20060699. doi: 10.1101/2020.04.10.20060699

21. Magagnoli J, Narendran S, Pereira F, et al. Outcomes of hydroxychloroquine usage in United States veterans hospitalized with Covid-19. medRxiv 2020:2020.04.16.20065920. doi: 10.1101/2020.04.16.20065920

22. Gautret $P$, Lagier JC, Parola $P$, et al. Hydroxychloroquine and azithromycin as a treatment of COVID19: results of an open-label non-randomized clinical trial. International Journal of Antimicrobial Agents 2020:105949. doi: 10.1016/j.ijantimicag.2020.105949 [published Online First: 2020/03/25]

23. Feng Z, Li J, Yao S, et al. The Use of Adjuvant Therapy in Preventing Progression to Severe Pneumonia in Patients with Coronavirus Disease 2019: A Multicenter Data Analysis. medRxiv 2020:2020.04.08.20057539. doi: 10.1101/2020.04.08.20057539

24. Chen X, Zhang Y, Zhu B, et al. Associations of clinical characteristics and antiviral drugs with viral RNA clearance in patients with COVID-19 in Guangzhou, China: a retrospective cohort study. medRxiv 2020:2020.04.09.20058941. doi: 10.1101/2020.04.09.20058941

25. Barbosa J KD, Freedman R, Le K, Lin X. Clinical Outcomes of Hospitalized Patients in Hospitalized Patients with COVID-19 : A Quasi-comparative Study. 2020:1-13.

26. Geleris J, Sun Y, Platt J, et al. Observational Study of Hydroxychloroquine in Hospitalized Patients with Covid-19. New England Journal of Medicine 2020 doi: 10.1056/NEJMoa2012410 
medRxiv preprint doi: https://doi.org/10.1101/2020.05.19.20106906; this version posted May 26, 2020. The copyright holder for this preprint (which was not certified by peer review) is the author/funder, who has granted medRxiv a license to display the preprint in perpetuity. All rights reserved. No reuse allowed without permission.

27. Molina JM, Delaugerre C, Le Goff J, et al. No evidence of rapid antiviral clearance or clinical benefit with the combination of hydroxychloroquine and azithromycin in patients with severe COVID19 infection. Medecine et Maladies Infectieuses 2020 doi: 10.1016/j.medmal.2020.03.006 [published Online First: 2020/04/03]

28. Gautret P, Lagier JC, Parola P, et al. Clinical and microbiological effect of a combination of hydroxychloroquine and azithromycin in 80 COVID-19 patients with at least a six-day follow up: A pilot observational study. Travel Medicine and Infectious disease 2020:101663. doi: 10.1016/j.tmaid.2020.101663 [published Online First: 2020/04/15]

29. Chorin E, Wadhwani L, Magnani S, et al. QT Interval Prolongation and Torsade De Pointes in Patients with COVID-19 treated with Hydroxychloroquine/Azithromycin. medRxiv 2020:2020.04.27.20074583. doi: 10.1101/2020.04.27.20074583

30. Ramireddy A, Chugh HS, Reinier K, et al. Experience with Hydroxychloroquine and Azithromycin in the COVID-19 Pandemic: Implications for QT Interval Monitoring. medRxiv 2020:2020.04.22.20075671. doi: 10.1101/2020.04.22.20075671

31. van den Broek MPH, Mohlmann JE, Abeln BGS, et al. Chloroquine-induced QTc prolongation in COVID-19 patients. Netherlands Heart Journal 2020 doi: 10.1007/s12471-020-01429-7 [published Online First: 2020/05/01]

32. Bessière $F$, Roccia H, Delinière $A$, et al. Assessment of QT Intervals in a Case Series of Patients With Coronavirus Disease 2019 (COVID-19) Infection Treated With Hydroxychloroquine Alone or in Combination With Azithromycin in an Intensive Care Unit. JAMA Cardiology 2020 doi: 10.1001/jamacardio.2020.1787 [published Online First: 2020/05/02]

33. Mercuro NJ, Yen CF, Shim DJ, et al. Risk of QT Interval Prolongation Associated With Use of Hydroxychloroquine With or Without Concomitant Azithromycin Among Hospitalized Patients Testing Positive for Coronavirus Disease 2019 (COVID-19). JAMA Cardiology 2020 doi: 10.1001/jamacardio.2020.1834 [published Online First: 2020/05/02]

34. Saleh M, Gabriels J, Chang D, et al. The Effect of Chloroquine, Hydroxychloroquine and Azithromycin on the Corrected QT Interval in Patients with SARS-CoV-2 Infection. Circulation: Arrhythmia and Electrophysiology; doi: doi:10.1161/CIRCEP.120.008662

35. Chorin E, Dai M, Shulman E, et al. The QT interval in patients with COVID-19 treated with hydroxychloroquine and azithromycin. Nature Medicine 2020 doi: 10.1038/s41591-020-0888-2

36. Official Statement from International Society of Antimicrobial Chemotherapy: Hydroxychloroquine and azithromycin as a treatment of COVID-19: results of an open-label non-randomized clinical trial (Gautret P et al. PMID 32205204). [published Online First: April 3rd]

37. Hulme OJ, Wagenmakers E-J, Damkier P, et al. A Bayesian reanalysis of the effects of hydroxychloroquine and azithromycin on viral carriage in patients with COVID-19. medRxiv 2020:2020.03.31.20048777. doi: 10.1101/2020.03.31.20048777

38. Chowdhury MS, Rathod J, Gernsheimer J. A Rapid Systematic Review of Clinical Trials Utilizing Chloroquine and Hydroxychloroquine as a Treatment for COVID-19. Academic Emergency Medicine 2020 doi: 10.1111/acem.14005 [published Online First: 2020/05/03]

39. Cortegiani A, Ingoglia G, Ippolito M, et al. A systematic review on the efficacy and safety of chloroquine for the treatment of COVID-19. Journal of Critical Care 2020 doi: 10.1016/j.jcrc.2020.03.005 [published Online First: 2020/03/17] 
medRxiv preprint doi: https://doi.org/10.1101/2020.05.19.20106906; this version posted May 26, 2020. The copyright holder for this preprint (which was not certified by peer review) is the author/funder, who has granted medRxiv a license to display the preprint in perpetuity.

All rights reserved. No reuse allowed without permission.

40. Shah S, Das S, Jain A, et al. A systematic review of the prophylactic role of chloroquine and hydroxychloroquine in coronavirus disease-19 (COVID-19). International Journal of Rheumatic Diseases 2020 doi: 10.1111/1756-185x.13842 [published Online First: 2020/04/14]

41. Singh AK, Singh A, Shaikh A, et al. Chloroquine and hydroxychloroquine in the treatment of COVID19 with or without diabetes: A systematic search and a narrative review with a special reference to India and other developing countries. Diabetes \& Metabolic Syndrome 2020;14(3):241-46. doi: 10.1016/j.dsx.2020.03.011 [published Online First: 2020/04/05]

42. Sarma $\mathrm{P}$, Kaur H, Kumar H, et al. Virological and clinical cure in COVID-19 patients treated with hydroxychloroquine: A systematic review and meta-analysis. Journal of Medical Virology 2020 doi: 10.1002/jmv.25898 [published Online First: 2020/04/17]

43. Should Clinicians Use Chloroquine or Hydroxychloroquine Alone or in Combination With Azithromycin for the Prophylaxis or Treatment of COVID-19? Annals of Internal Medicine;0(0):null. doi: 10.7326/m20-1998

44. Million M, Lagier JC, Gautret P, et al. Full-length title: Early treatment of COVID-19 patients with hydroxychloroquine and azithromycin: A retrospective analysis of 1061 cases in Marseille, France. Travel Medicine and Infectious Disease 2020:101738. doi: 10.1016/j.tmaid.2020.101738 [published Online First: 2020/05/11]

45. Rosenberg ES, Dufort EM, Udo T, et al. Association of Treatment With Hydroxychloroquine or Azithromycin With In-Hospital Mortality in Patients With COVID-19 in New York State. JAMA 2020 doi: 10.1001/jama.2020.8630 [published Online First: 2020/05/12]

46. Alexander PE, Debono VB, Mammen MJ, et al. COVID-19 coronavirus research has overall low methodological quality thus far: case in point for chloroquine/hydroxychloroquine. Journal of Clinical Epidemiology 2020 doi: 10.1016/j.jclinepi.2020.04.016 [published Online First: 2020/04/25] 
medRxiv preprint doi: https://doi.org/10.1101/2020.05.19.20106906; this version posted May 26, 2020. The copyright holder for this preprint (which was not certified by peer review) is the author/funder, who has granted medRxiv a license to display the preprint in perpetuity.

All rights reserved. No reuse allowed without permission.

\begin{tabular}{|c|c|c|c|c|c|}
\hline Study & Country & $\begin{array}{l}\text { Patients, } \\
\text { number }\end{array}$ & $\begin{array}{l}\text { Hospitals, } \\
\text { number }\end{array}$ & Treatment & Comparator \\
\hline \multicolumn{5}{|c|}{ Randomized controlled Trials } & \\
\hline Borba et al $2020^{18}$ & Brazil & 81 & 1 & $\mathrm{CQ}$ & Low dose $\mathrm{CQ}$ \\
\hline Chen et al (a) $2020^{16}$ & China & 62 & 1 & $\mathrm{HCQ}$ & Usual care \\
\hline Chen et al (b) $2020^{17}$ & China & 30 & 1 & $\mathrm{HCQ}$ & Usual care \\
\hline Huang et al $2020^{19}$ & China & 22 & 1 & $\mathrm{HCQ}$ & Lopinavir/ritonavir \\
\hline Tang et al $2020^{15}$ & China & 150 & 16 & $\mathrm{HCQ}$ & Usual care \\
\hline \multicolumn{6}{|l|}{ Observational studies } \\
\hline Barbosa et al $2020^{25}$ & USA & 63 & 2 & $\mathrm{HCQ}$ & Usual care \\
\hline Chen et al (c) $2020^{24}$ & China & 284 & 1 & $\mathrm{CQ}$ & Usual care \\
\hline Feng et al $2020^{23}$ & China & 50 & 1 & $\mathrm{CQ}$ & Usual care \\
\hline Gautret et al 2020 (a) ${ }^{22}$ & France & 46 & 4 & $\mathrm{HCQ}$ & Usual care \\
\hline Geleris et al $2020^{26}$ & US & 1446 & 1 & $\mathrm{HCQ}$ & $\begin{array}{l}\text { Usual care/matched } \\
\text { cohort }\end{array}$ \\
\hline Mahevas et al $2020^{20}$ & France & 181 & 4 & $\mathrm{HCQ}$ & Usual care \\
\hline Magagnoli et al $2020^{21}$ & US & 368 & 170 & $\begin{array}{c}\mathrm{HCQ} / \\
\mathrm{HCQ}+\mathrm{AZ}\end{array}$ & $\begin{array}{l}\text { Males, matched } \\
\text { cohort }>65 \text { yrs }\end{array}$ \\
\hline Gautret et al (b) $2020^{28} \dagger$ & France & 80 & 1 & $\mathrm{HCQ}+\mathrm{AZ}$ & None \\
\hline Molina et al $2020^{27} \dagger$ & France & 11 & 1 & $\mathrm{HCQ}+\mathrm{AZ}$ & None \\
\hline \multicolumn{6}{|c|}{ † Uncontrolled observational studies. The remaining observational studies were controlled. } \\
\hline \multicolumn{5}{|c|}{ Abbreviations: $\mathrm{AZ}=\mathrm{Azithromycin;} \mathrm{CQ}=\mathrm{Chloroquine;} \mathrm{HCQ}=\mathrm{Hy}$ droxychloroquine, } & \\
\hline
\end{tabular}


medRxiv preprint doi: https://doi.org/10.1101/2020.05.19.20106906; this version posted May 26, 2020. The copyright holder for this preprint (which was not certified by peer review) is the author/funder, who has granted medRxiv a license to display the preprint in perpetuity. All rights reserved. No reuse allowed without permission.

Table 2. Virologic and clinical outcomes for hydroxychloroquine and chloroquine in patients hospitalized with COVID-19

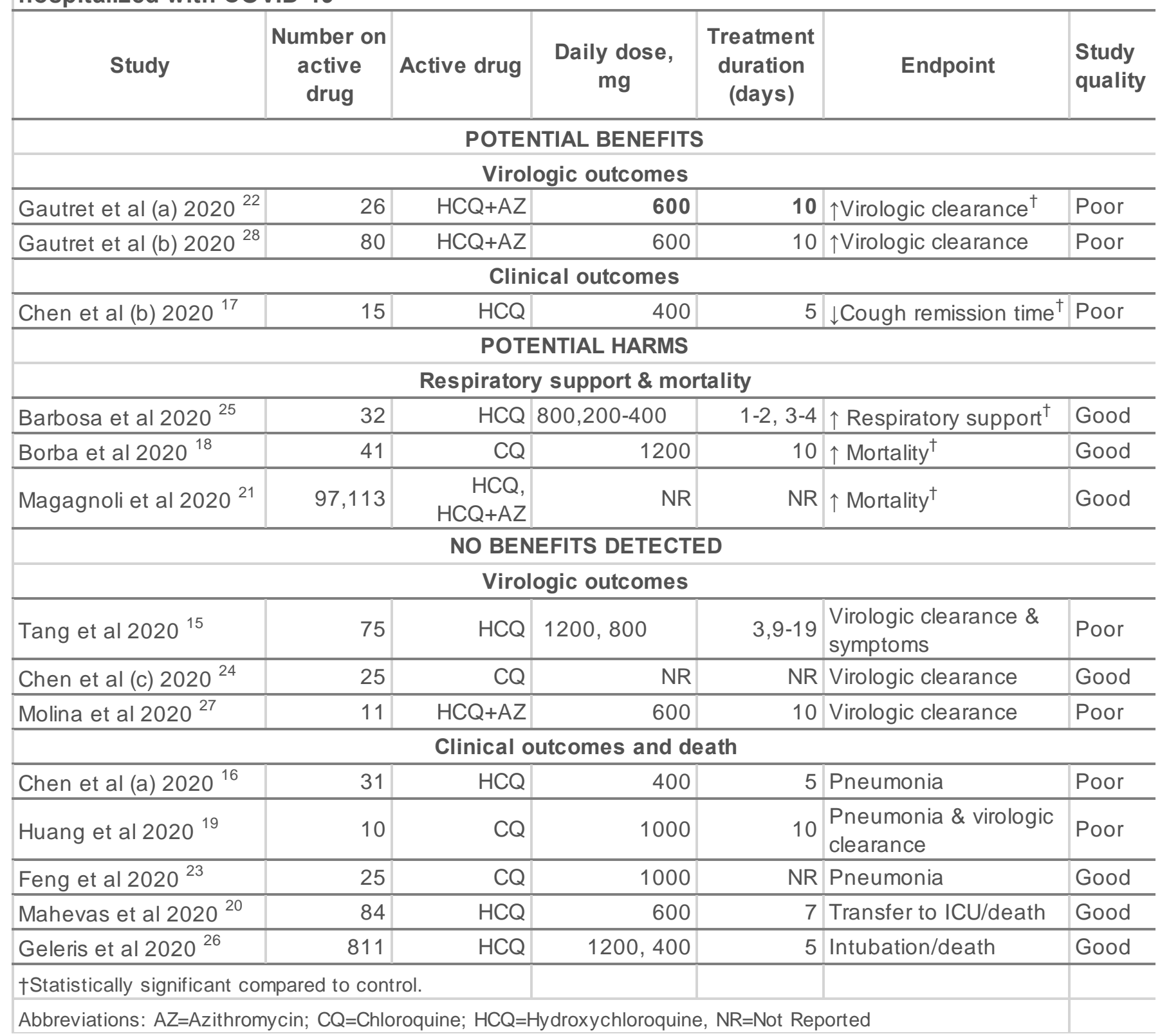


medRxiv preprint doi: https://doi.org/10.1101/2020.05.19.20106906; this version posted May 26, 2020. The copyright holder for this preprint (which was not certified by peer review) is the author/funder, who has granted medRxiv a license to display the preprint in perpetuity.

Figure 1. PRISMA systematic review flow diagram

Records identified through database searching in Pubmed and clinicaltrials.gov on April 262020

$$
(n=124)
$$
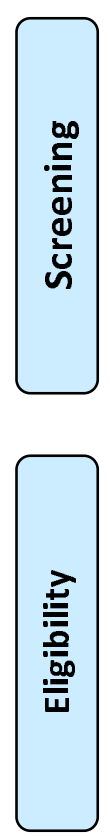

웜

From: Moher D, Liberati A, Tetzlaff J, Altman DG, The PRISMA Group (2009). Preferred Reporting Items for Systematic Reviews and MetaAnalyses: The PRISMA Statement. PLoS Med 6(7): e1000097. doi:10.1371/journal.pmed1000097
Records excluded $(n=128)$

Case reports (11)

Invitro studies (6)

No original data (16)

Non-COVID (3)

Review (75)

Systematic reviews/protocols (17)

Full-text articles excluded, with

$$
\begin{aligned}
& \text { reasons } \\
& (n=32)
\end{aligned}
$$

Non-relevant intervention (12)

Non-relevant outcome (2)

Non-relevant (15)

Non-relevant design (3)

studies

( $n=12$ )

New studies from included article citations and electronic notifications

$(n=8)$
Studies included in qualitative synthesis ( $n=20$ )

Clinical outcomes (14)

EKG (6) 


\section{Figure 2. Critical QTc Prolongation in Studies of Chloroquine/ Hydroxychloroquine in Patients with COVID-19 ( $n=8)$}

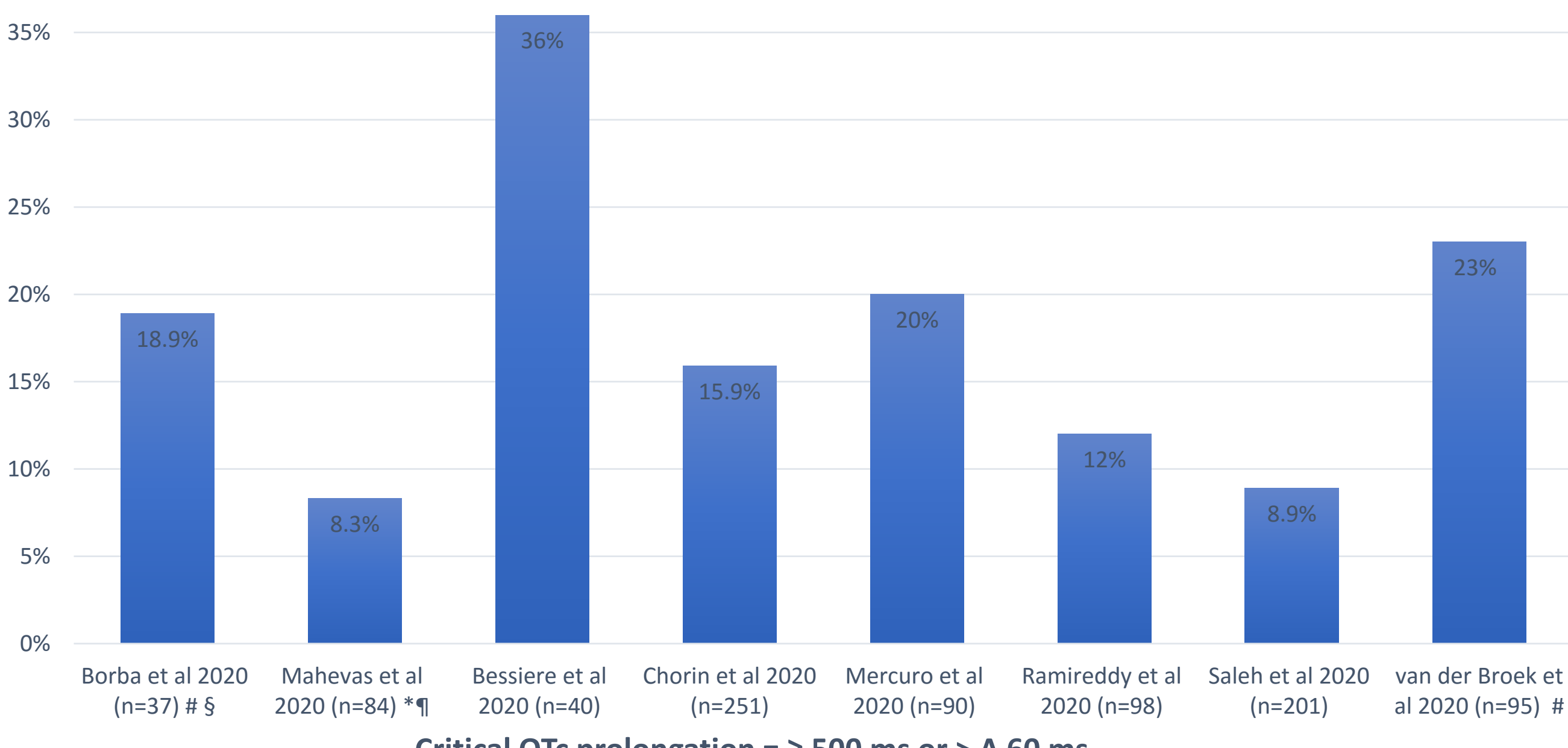

\section{Critical QTc prolongation $=\geq 500 \mathrm{~ms}$ or $>\Delta 60 \mathrm{~ms}$}

\#Chloroquine alone in Borba et al and van der Broek et al ; * Hydroxychloroquine alone in Mahaves et al. The remaining 5 studies used combination of hydroxychloroquine and azithromycin $\S$ Borba et al was a controlled clinical trial where low dose CQ arm also experienced critical QTc prolongation (11.1\%)

I Mahevas was a controlled observational study where the control arm did not report any QTc prolongation. The remaining 6 studies were uncontrolled observational cohorts 